\title{
Importance of Farmers Awareness Programme under Gramin Krishi Mausam Sewa Project AMFU: Pundibari
}

\author{
Debasis Mahata ${ }^{*}$, Anwesh Rai ${ }^{2}$ and Subhendu Bandyopadhyay ${ }^{3}$ \\ Department of Agronomy, Uttar BangaKrishiViswavidyalaya, Pundibari, Cooch Behar, \\ West Bengal-736165, India \\ *Corresponding author
}

\section{A B S T R A C T}

The importance of Gramin Krishi Mausam Sewa is well recognized in present agricultural

Keywords

Gramin Krishi

Mausam Sewa,

Agromet Advisory

Bulletin

Article Info

Accepted:

24 January 2018

Available Online:

10 February 2018 scenario which needs sustainable development to feed rapidly growing population of the nation. Weather based agriculture is highly beneficial for the farmers of India to sustain their profession for earning bread and butter. The advisory helps them to optimize the use of available resources for maximization of their profit. When the forecast is proved correct it gives benefit to the farmers, if it is not so, then there is hardly any loss to the farmers. The issuance of 'Forecast based Agromet Advisory Bulletin from AMFU Pundibari has been continuing since June '2005. It is in fact a good platform to provide the Advisories from the scientists of different disciplines of agriculture, with a special emphasis on weather based interaction of various crop, their diseases, pests etc. In this way Gramin Krishi Mausam Sewa provides invaluable services to the farming community of Cooch Behar, Jalpaiguri and North Dinajpur districts under Terai region of West Bengal which experiences sometimes abnormal weather conditions i.e. very high rainfall, intermittent drought spell during rainy season etc. Most of the farmers practice rainfed agriculture in this area. Therefore, this project is very much essential to cater the location specific needs of the local farmers.

\section{Introduction}

Farmers' Awareness Programme was organized on $24^{\text {th }}$ January, 2017 by AMFU: Pundibari at Dhuliagacch, Chopra, Uttar Dinajpur, West Bengal.

Total number of eighty farmers from different villages, Dhuliagach, Goalgach, Molanigachhin, Chopra Block, Uttar Dinajpur district participated in the awareness programme. Scientific persons from
University and KVK, representative from NGO, Club in Uttar Dinajpur District was present in the event. (Dr.) Dhananjoy Mandal, Programme co-ordinator Uttar Dinajpur, KVK, UttarBanga Krishi Viswavidyalaya, inaugurated the programme and spoke on importance of weather based agro- advice in the changing scenario of climate of North Bengal. and importance of weather based agro-advice. Dr. Subhendu Bandyopadhyay, Nodal Officer of the project delivered the welcome address. 
The technical session started at 11:30 am with the speech 'Climate change vis-a-vis Agriculture in North Bengal' by Dr. Subhendu Bandyopadhyay Nodal Officer, AMFU: Pundibari. He highlighted the importance of different weather elements on plant growth and with the 50 years of weather data he tried to match with the farmers' perception regarding the change in climate that already has been taken place in different districts of North Bengal. He also explained the climate induced adjustment in terms of crop, variety and management practices that has already occurred and that has to be occurred to maintain the sustainability and profitability in the system as a whole in North Bengal. He also explained the significance of weather forecasting on agriculture and sphere \& way of activity of the project, 'Gramin Krishi Mousam Sewa' and underlined the significance of different type of weather forecasting on day to day agricultural activities and long term planning and also emphasized the importance of Advisory bulletin to reach among entire farming community for the betterment of agriculture in Uttar Dinajpur District. Dr. Subhendu Bandyopadhyay told that this agro advisory bulletin is being issued in three steps viz. national level, state level and district level.

Bulletin contains several aspects like planning of kharif crop depending on onset of monsoon, sowing of rabi crop depending on residual moisture condition of soil, fertilizer application depending on time and amount of rainfall, preventive measure of disease and pest depending on weather condition etc. Next speaker Dr. Dhananjoy Mandal, ProgrammeCoordinator Uttar Dinajpur, KVK underlined the 'Weather dependent disease occurrence and its management in North Bengal. Dr. Mandal described in detail about the diseases of the principle crops like rice, wheat, different vegetables, pulses, cash crops etc., their favourable climatic requirement for occurrence and their suitable management practices farmers can easily afford (Table 1)

\section{Interactive session}

In the interactive session the farmers told that they are interested in the agro advisory bulletin published in the daily newspaper. Pradyutkumar Biswas realized that the Farmers' awareness programme is very useful to them. He also emphasized on the perfect collaboration among University, KVKs, State Agriculture Department and NGOs for getting better output in this aspect.

Kishor Tappo from Dhuliagachh told that he is benefited by the Agro Advisory Bulletin and used to watch this bulletin in the newspaper regularly. He shared his experience that he got the information from the bulletin about the occurrence of rainfall. He is interested in the telephonic message of weather forecasting. Ramesh Khalko from Chopra told that they faced adverse climatic condition like hail storm etc, but they are not getting any forecasting about this type of adverse weather condition. Hail strom damage to pineapple.

The farmers also interested in the topics which was delivered in different session and asked different question. Some of the conversations are as follows:

(Kishor Tapoo from Dhuliagachh, Chopra, Uttar Dinajpur): We are very much benefited from this programme and we need this type of training programe in the village level also. How can the AMFU help us?

Ans: Dr. Subhendu Bandyopadhyay replied thatwe can help individually but if we want to involve the team of scientists and Research Associate for frequent field visit.

(SushilTirki from Chopra, Uttar Dinajpur): how to control mustard aphid and leaf spot. 
Ans: Dr. Debasis Mahata (Research Associate) answered that if aphid infestation exceeds ETL, apply Imidochloprid 17.8 SL @ $1 \mathrm{ml} / 5$ lit of water. If leaf spot appears, then apply Mancozeb@2.5 g/lit of water.

\section{Questionnaire}

The several interesting information surfaced from the Questionnaire. The main cultivated crop in this district is rice, wheat, vegetables, Pineapple and tea etc. Forty percent farmers are aware of the agro advisory bulletin but $30 \%$ said that they did not know about the service. Rest of the farmers did no comment on this aspect. Out of aware farmers, 67\% received this bulletin through Newspaper, $20 \%$ from both Newspaper and farmers' club, $11 \%$ through farmers' club only and $2 \%$ through television. The farmers also preferred to have this service through e-mail, leaflet and mobile SMS.

From the Questionnaire we came to know that they preferred the information in the bulletin like proper time of land preparation, proper time of sowing, amount of rainfall, preventive measure of disease pest depending upon the weather condition, time of fertilizer application and amount of application and irrigation schedule.

\section{How many farmers received the AAS bulletin in time and the media?}

Survey was conducted among the farmers. Out of aware farmers, $38 \%$ received this bulletin through Newspaper only; $42 \%$ from more than one media like, Newspaper, Television and mobile SMS; $20 \%$ from KPS, farmers' club, television and newspaper.

\section{Specific comments made by farmers?}

Kiran Barman told that they used to receive the bulletin form AMFU, Pundibari through e- mail, Farmers' portal (SMS) print and electronic media on regular basis and disseminate to the other farmers to make them aware about the importance of weather in agricultural production.

Kishor Tapoo from Dhuliagachh, Chopra, Uttar Dinajpur told that they usually face higher difficulties during heavy rainfall and or drought where solution and advisory from experts in this situation will work as their real friend.

Md. Mojayet Hossain from Dinhata-II Block, Coochbehar district told that he is benefited by the Agro Advisory Bulletin and get updated information from $\mathrm{TV}$, radio and newspaper on regular basis.

Some farmers informed that in some days forecast did not match with the forecast.

The weather forecast was received by the AAS Unit, Pundibari twice in a week (on every Tuesday and Friday) from RMC Kolkata, IMD, Govt. of India.

The weather forecasts so obtained for Cooch Behar district during the period under study (study period: 2016-2017) were compared with the observed weather data of Pundibari Automatic Weather Station (Table 2).

Qualitative as well as quantitative verification were conducted as per guidelines/ methodologies provided by IMD. From 01.04.2016 to 31.03.2017.

Verification study was done for the following meteorological parameters:

Rainfall (mm)

Maximum temperature $\left({ }^{0} \mathrm{C}\right)$

Minimum temperature $\left({ }^{0} \mathrm{C}\right)$ 
Table.1 Types of crops grown by the farmers

\begin{tabular}{|l|l|}
\hline $\begin{array}{l}\text { Type of crop } \\
\text { Cereals }\end{array}$ & $\begin{array}{l}\text { Rice, Wheat, Maize } \\
\text { cabbage, cauliflower, brocoli, chilli, brinjal, potato, ladies finger, tomato, } \\
\text { spine gourd, bitter gourd } \\
\text { Vegetables }\end{array}$ \\
\hline Oil seeds & $\begin{array}{l}\text { Mango, Banana } \\
\text { Tuberose, Marigold, Chrysanthemum }\end{array}$ \\
\hline Fruits & Betelvine, Tea, Tobacco \\
\hline Plantation crops & ginger, onion, garlic \\
\hline Spice crop & Jute \\
\hline Fiber crop & Cows, Poultry \\
\hline Animals &
\end{tabular}

Number of farmers from which feedback were received: 80

Table.2 Rating feedback of weather forecast by 80 progressive farmers

\begin{tabular}{|l|l|l|l|}
\hline SI No. & Particulars & No. of farmers & Percentage \\
\hline 1. & Excellent & 35 & 43.75 \\
\hline 2. & Very good & 25 & 31.25 \\
\hline 3. & Good & 15 & 18.75 \\
\hline 4. & Satisfactory & 5 & 6.25 \\
\hline 5. & Irrelevant & - & - \\
\hline 6. & Did not answer & - & - \\
\hline
\end{tabular}

Table.3 Daily rainfall analysis for the year 2016-2017

\begin{tabular}{|l|l|}
\hline Parameters & From $1^{\text {st }}$ A pril, 2016 to $31^{\text {st }}$ March, 2017 \\
\hline RMSE value & 20.14 \\
\hline 'r' value & 0.25 \\
\hline Ratio score/Hit score (\%) & 85.95 \\
\hline Critical Success Index/ Threat score & 0.65 \\
\hline HK score & 0.79 \\
\hline Error structure (\%) & \\
\hline Correct & 71.15 \\
\hline Usable & 4.81 \\
\hline Unusable & 24.04 \\
\hline
\end{tabular}

Table.4 Maximum temperature analysis for the year 2016-2017

\begin{tabular}{|l|}
\hline Parameters \\
\hline RMSE value \\
\hline 'r' value \\
\hline Error structure (\%) \\
\hline Correct \\
\hline Usable \\
\hline Unusable \\
\hline
\end{tabular}

\section{From $1^{\text {st }}$ April, 2016 to $31^{\text {st }}$ March, 2017}

\subsection{5}

0.67

43.44

27.05

29.51 
Table.5 Minimum temperature analysis for the year 2016-2017

\begin{tabular}{|l|l|}
\hline Parameters & From ${ }^{1 \mathrm{st}}$ April, 2016 to 31 $^{\text {st }}$ March, 2017 \\
\hline RMSE value & 1.72 \\
\hline 'r' value & 0.94 \\
\hline Error structure (\%) & \\
\hline Correct & 58.20 \\
\hline Usable & 21.31 \\
\hline Unusable & 20.49 \\
\hline
\end{tabular}

Table.6 Specific instances of benefit/ loss due to AAS with cultural practices modified as per advisories

\begin{tabular}{|c|c|c|c|}
\hline Crop & Forcasted events & $\begin{array}{l}\text { Crop/Animal Husbandry/Cultural operations } \\
\text { recommended in advisory }\end{array}$ & $\begin{array}{l}\text { Benefit/Loss } \\
\text { (Rs/bigha) }\end{array}$ \\
\hline Jute & $\begin{array}{l}\text { Possibility of heavy } \\
\text { rain during monsoon } \\
\text { months. }\end{array}$ & $\begin{array}{l}\text { As heavy rainfall occurred, farmers were advised to harvest } \\
\text { the rainwater in ponds or ditches as clean water is required for } \\
\text { ratting of jute. But during the harvest time of jute i.e., in the } \\
\text { month of July, a long rain less period was prevailed. } \\
\text { Therefore, the farmers who harvested rain water during } \\
\text { monsoon can utilized the water for proper ratting of jute. }\end{array}$ & $2,500 /-$ \\
\hline Boro Rice & $\begin{array}{l}\text { Low temperature } \\
\text { during germination } \\
\text { period }\end{array}$ & $\begin{array}{l}\text { The forecast was given regarding possibility of very low } \\
\text { temperature, poor germination and delay in maturity. Farmers } \\
\text { who followed the advisory could avoid such type of problem } \\
\text { by adopting the seedbed management practices against the low } \\
\text { temperature oriented problem. }\end{array}$ & $1,500 /-$ \\
\hline Potato & $\begin{array}{l}\text { Low temp. with } \\
\text { cloudy weather }\end{array}$ & $\begin{array}{l}\text { Forecast was given regarding possibility of lower temperature } \\
\text { and cloudy weather late blight attack may initiate. To manage } \\
\text { the disease preventive measures were given as follows } 1 . \\
\text { Spray Cymoxanil }(8 \%)+\text { Mancozeb (64\%) @ } 1.5 \mathrm{gm} / \mathrm{lt} \text { of } \\
\text { water at } 8-10 \text { days interval } 2 \text {. or spray Dimethomorph }(50 \%) \\
1.5 \mathrm{gm}+\text { Mancozeb } 2 \text { gm per lt of water. } 3 \text {. Withheld } \\
\text { irrigation and restricted use of nitrogenous fertilizers top } \\
\text { dressing. } 4 \text {. Apply } 5 \mathrm{~kg} \text { MOP / Bigha as top dressing. Farmers } \\
\text { followed these advise were benefited. }\end{array}$ & $55,000 /-$ \\
\hline $\begin{array}{l}\text { Animal } \\
\text { Husbandr } \\
\text { y }\end{array}$ & $\begin{array}{l}\text { During winter season } \\
\text { very low temperature } \\
\text { (less than } 15^{\circ} \mathrm{C} \text { ), low } \\
\text { humidity will prevail }\end{array}$ & $\begin{array}{l}\text { In low temperature condition the advisory was given for } \\
\text { new born animal or chick to provide with artificial heat and } \\
\text { to protect them from chilling especially at night. Farmers } \\
\text { adopted this practice was benefited. }\end{array}$ & $\begin{array}{l}\text { Poultry (RIR): } \\
155 /- \text { per } 10 \\
\text { birds Pigerry: } \\
\text { 2500/- per sow } \\
\text { with newborn } \\
\text { litter. }\end{array}$ \\
\hline Betel vine & $\begin{array}{l}\text { Low temp. foggy } \\
\text { weather }\end{array}$ & $\begin{array}{l}\text { Top of the boroj should make dense to protect from low } \\
\text { temperature, dew and fog. Susi Dev from } \\
\text { AlipurJalpaiguribenifited from the recommendation. }\end{array}$ & $41,000 /-$ \\
\hline Brinjal & $\begin{array}{l}\text { High temp. and high } \\
\text { soil moisture }\end{array}$ & $\begin{array}{l}\text { For this apply } 2 \mathrm{~kg} \text { bliching powder with irrigation water par } \\
\text { bigha of land. Farmer from Cooch Behar benifited from the } \\
\text { recommendation. }\end{array}$ & $16,300 /-$ \\
\hline
\end{tabular}


Daily rainfall, maximum temperature, minimum temperature analysis

Daily rainfall analysis for the year 20162017

Daily rainfall data was analyzed with the forecasted value and the results are presented in Table 3.

Quantitative verification: If the data set from $1^{\text {st }}$ April, 2016 to $31^{\text {st }}$ March, 2017 was considered it was observed that the r-value is moderate $(0.25)$ and the RMSE value is 20.14 .

Qualitative verification: The ratio score of was at considerably good (85.95) level. The other indices of rainfall accuracy such as Critical Success Index/ Threat score and HK score are also worked out and presented in Table 3.

The error structure shows that the success rate (i.e. the percentage of correct plus usable forecast) was considerably good $(71.15 \%)$ for the time period.

Maximum temperature analysis for the year 2016-2017

Daily Maximum temperature data was analyzed with the forecasted value and the results are presented in Table 4. Quantitative verification: If the data set from $1^{\text {st }}$ April, 2016 to $31^{\text {st }}$ March, 2017 was considered it was observed that the r-value is moderate (0.67) and the RMSE value is 1.85 .

Qualitative verification: The error structure shows that the success rate (i.e. the percentage of correct plus usable forecast) was moderate $(70.49 \%)$ for the time period.

Daily Minimum temperature data was analyzed with the forecasted value and the results are presented in Table 5. Quantitative verification: If the data set from $1^{\text {st }}$ April, 2016 to $31^{\text {st }}$ March, 2017 was considered it was observed that the r-value is considerably high (0.94) and the RMSE value is 1.72. It indicates the minimum temperature forecast matches well with observed data.

Qualitative verification: The error structure shows that the success rate (i.e. the percentage of correct plus usable forecast) was considerably good $(79.51 \%)$ for the time period.

\section{Economic impact assessment of the AAS}

Survey was conducted among the contact farmers through the feedback form and found that agro-advisory is very much useful to the farmers. It helps the farmers not only to protect the crop from different climatic hazards but also to plan their input management activity in advance to minimize the cost of cultivation and improve the quality production.

Specific instances of benefit/ loss due to AAS with cultural practices modified as per advisories

The overall advisories regarding irrigation scheduling, different farming operations, forecast related to incidences of pest and diseases along with control measures, crop planning for rainfed and irrigated situations etc. were very much helpful and popular among the farming community. As for example: Farmers also gave their opinion to improve the service. Their opinions are like this: Village level Farmers Awareness Progmmme should be organized more frequently. Involvement of more media like more farmers club, Self Help Group, Different welfare organization, different NGOs should be done (Table 6). 
Mobile phone SMS to the individual farmers or the progressive farmers and local public representative.

Direct contact to the farmers and field visit. Creation of village level knowledge hub

Finally Dr. Subhendu Bandyopadyaya, Nodal officer AMFU: Pundibari gave the vote of thanks to all the resource persons for their valuable technical input and making the progamme useful and other Scientific persons from University and KVK.

Follow up action taken by AMFU after Farmers Awareness Programme

In the programme Dr. Subhendu Bandyopadhyaya promised that AMFU is trying to involve NGOs, Farmers club, state agriculture department and other organization to disseminate the bulletin among maximum no of farmers. AMFU has already made the contact with different organization like, media, Bank, NGOs, Farmers' club etc. for the speedy dissemination of bulletin. Programme coordinator KVK, Dr. Dhananjoy Mandal told they have registered farmers he is interested in disseminating the Agro advisory Bulletin.

\section{References}

Agro Advisory Bulletin, AMFU-Pundibari, Uttar Banga Krishi Viswa Vidyalaya,
Pundibari, Cooch Behar, West Bengal, India.

Cooch Behar Krishi Vigyan Kendra, Cooch Behar, West Bengal, India.

Department of Agricultural Extension, Uttar Banga Krishi Viswa Vidyalaya, Pundibari, Cooch Behar, West Bengal, India.

Department of Agronomy, Uttar Banga Krishi Viswa Vidyalaya, Pundibari, Cooch Behar, West Bengal, India.

Farmers Awareness programme, of Dhuliagacch, Chopra, Uttar Dinajpur, West Bengal, India.

Farmers Club, Satmile Satish Club "O" Pathagar, Cooch Behar, West Bengal, India.

Gramin Krishi Mausam Sewa project (GKMS), India. Meteorological Department, Ministry of Earth Science. Government of India.

Mojhait Hossain, Sabuj Biplab Producer Organization, Farmers Club, Cooch Behar, West Bengal, India.

Regional Meteorological Centre, Kolkata, IMD, Govt. of India.

Uttar Dinajpur Krishi Vigyan Kendra, Chopra, Uttar Dinajpur, West Bengal, India.

Willmott, C. and Matsuura, K.: Advantages of the mean absolute error (MAE) over the root mean square error (RMSE) in assessing average model performance, Clim. Res., 30, 79-82, 2005.

\section{How to cite this article:}

Debasis Mahata, Anwesh Rai and Subhendu Bandyopadhyay. 2018. Importance of Farmers Awareness Programme under Gramin Krishi Mausam Sewa Project AMFU: Pundibari. Int.J.Curr.Microbiol.App.Sci. 7(02): 2678-2684. doi: https://doi.org/10.20546/ijcmas.2018.702.324 